\title{
Emerging therapies for the treatment of cholangiocarcinoma
}

\author{
Sean Turbeville, Carl S. Hornfeldt, Milind Javle, \\ Eric Tran, Marion Schwartz
}

\begin{abstract}
Cholangiocarcinoma (CCA) is a cancer arising from the epithelium of intrahepatic or extrahepatic bile ducts. Cholangiocarcinoma often has a poor prognosis due to late diagnosis and the incidence and mortality rate of intrahepatic CCA appear to be increasing. Current therapies include surgical resection, orthotopic liver transplantation, chemotherapy/ chemoradiation and palliative care. Depending on the location, the 5-year survival for CCA ranges from 27-60\%. Emerging new therapies are currently being developed for treating CCA include immunotherapy, altering the tumor microenvironment, targeting growth factor gene mutations and signal pathways and that control tumor growth, and targeting gene therapy. The objective of this paper is to summarize the research that is currently ongoing for treating this challenging disease.
\end{abstract}

Keywords: Cholangiocarcinoma, Immunotherapy, Molecular targeting, Mutation profiling, Tumor microenvironment

Sean Turbeville ${ }^{1}$, Carl S. Hornfeldt ${ }^{2}$, Milind Javle ${ }^{3}$, Eric Tran $^{4}$, Marion Schwartz ${ }^{1}$

Affiliations: ${ }^{1}$ The Cholangiocarcinoma Foundation, Salt Lake City, Utah; ${ }^{2}$ Apothekon, Inc., Woodbury, MN; ${ }^{3}$ University of Texas MD Anderson Cancer Center, Houston, TX; ${ }^{4}$ Earle A. Chiles Research Institute, Portland, OR.

Corresponding Author: Dr. Carl S. Hornfeldt, Apothekon, Inc., 724 Bielenberg Drive Suite 124, Woodbury, MN 55125; Email: carl.hornfeldt@apothekon.com

Received: 05 June 2017

Accepted: 08 September 2017

Published: 25 September 2017

\section{How to cite this article}

Turbeville S, Hornfeldt CS, Javle M, Tran E, Schwartz M. Emerging therapies for the treatment of cholangiocarcinoma. Int $\mathrm{J}$ Hepatobiliary Pancreat Dis 2017:7:36-49.

Article ID: 100072IJHPDST2017

$* * * * * * * * *$

doi:10.5348/ijhpd-2017-72-RA-8

\section{INTRODUCTION}

\section{Description}

Cholangiocarcinoma (CCA) is a cancer arising from the epithelium of intrahepatic or extrahepatic bile ducts caused by the malignant transformation of hepatic biliary cholangiocytes $[1,2]$. Cholangiocarcinoma can occur anywhere from the small peripheral hepatic ducts to the distal common bile duct [2]. The three primary types of CCA and their relative frequency are intrahepatic (10\%), distal (40\%) and perihilar (50\%), the latter being confined to the larger bile ducts in the hepatic hilum. Mixed hepatocellular cholangiocarcinomas have recently been described in which CCA and hepatocellular carcinoma are found in the same nodule [2]. Cholangiocarcinoma primarily arises from the biliary epithelium in the case of extrahepatic cholangiocarcinoma while hepatic progenitors are believed to play a role in intrahepatic CCA [3]. Cholangiocarcinomas have a dense stromal component that result from the recruitment of fibroblasts, remodeling of the extracellular matrix, altered immune cell migration, and angiogenesis. The tumor stroma surrounds the malignant ducts and glands and comprises most of the tumor mass [4]. 


\section{Epidemiology}

Cholangiocarcinoma is the second most common primary liver tumor with estimates ranging from $10-25 \%$ of all hepatobiliary malignancies [1]. The age-adjusted incidence of CCA ranges from a high of 2.8-3.3 per 100,000 among Hispanic and Asian populations to a low of 2.1 per 100,000 among non-Hispanic white and black people and is slightly more prevalent among men [2]. Several recent epidemiological studies have shown that the incidence and mortality rates of intrahepatic CCA are increasing [5].

In one series, five-year survival rates for intrahepatic, perihilar and distal cholangiocarcinoma were $60 \%$, $30 \%$ and $27 \%$ respectively [6]. Median and five-year overall survival (OS) for intrahepatic CCA after surgical resection were 28 months (range: 9-53 months) and 30\% (range: $5-56 \%$ ), respectively [7]. Factors predicting shorter OS included large tumor size, multiple tumors, lymph node metastasis, and vascular invasion. Adjuvant chemotherapy or radiotherapy did not appear to be beneficial. With the exception of advanced patient age, factors associated with shorter OS are tumor-related and include larger tumor size, presence of multiple tumors, lymph node metastasis, vascular invasion, and poor tumor differentiation [7].

\section{Risk Factors}

Cholangiocarcinoma frequently arises under conditions of chronic inflammation which is believed to contribute to pathogenesis [8]. In the Western world, primary sclerosing cholangitis (PSC) and fatty liver disease resulting in chronic inflammation of the biliary tree represent the most common predisposing conditions for CCA $[8,9]$. Other proposed risk factors include alcohol consumption [10], diabetes mellitus $[10,11]$, opisthorchiasis (hepatobiliary flukes) $[12,13]$, choledochal cysts [14], chronic hepatitis B and C [10, 15], obesity $[10,15,16]$, cirrhosis [10], hepatolithiasis [17], and chemical carcinogens [5].

\section{Diagnosis}

The clinical presentation of CCA patients varies according to the clinical type. Patients with intrahepatic CCA present with abdominal pain, malaise, night sweats, weight loss and anorexia. Patients with extrahepatic CCA typically present with symptoms of obstructive jaundice and sometimes with complications such as cholangitis, which represents a major cause of morbidity in this population [18].

There are few approved serum biomarkers for detecting cancer and none are specific for CCA [19]. Fluorescence in situ hybridization (FISH) has high specificity for CCA and maybe useful for patients at high-risk for CCA, such as those with primary sclerosing cholangitis (PSC) [20, 21]. However, this test has relatively poor specificity, especially in the presence of jaundice. Better biomarkers are needed for the early detection of CCA. Immunohistochemical methods can be used to distinguish intrahepatic cholangiocarcinoma and pancreatic ductal adenocarcinoma [22]. The measurement of volatile organic compounds in biliary fluid is emerging as a possible method for diagnosing CCA in patients with PSC [23]. The lack of early diagnostic biomarkers results in late diagnosis and poor prognosis. Thus, $80 \%$ patients with CCA will present with unresectable or metastatic disease with poor prognosis [24].

Ultrasonography, computed tomography (CT) scan and magnetic resonance imaging (MRI) scan are the most common non-invasive imaging modalities used in the diagnosis and staging of hilar cholangiocarcinoma [25]. Endoscopic ultrasound is emerging as a useful tool for the diagnosis and staging of CCA [26].

\section{CURRENT THERAPIES}

\section{Surgery}

The treatment of choice for intrahepatic CCA is surgical resection. Surgical treatments are the only potentially curative therapeutic options for intrahepatic CCAs. Unfortunately, only a minority of patients qualify for surgical resection as most present with advanced unresectable disease [18]. Following surgical resection, the median time of disease-free survival is 26 months and five-year survival ranges from 30-60\% [3]. There are no large randomized controlled trials demonstrating a survival benefit of combining neoadjuvant or adjuvant chemotherapy with surgical resection [18].

\section{Orthotopic liver transplantation}

Liver transplantation has not yet been shown to be a viable option for intrahepatic CCA as disease recurrence was reported to be as high as $70 \%$ within five years [27]. However, liver transplantation has been shown to result in significant clinical benefit for select patients with hilar CCA following neoadjuvant chemoradiation $[28,29]$. This modality typically involves preoperative chemoradiation and resulted in $75 \%$ five-year survival for these patients. The selection criteria for transplant as rigorous, however, and a few patients qualify for this therapy [30]. For early stage hilar CCA, surgical resection remains the standard of care and transplant is an option for selected small but unresectable cases of hilar CCA.

\section{Chemotherapy}

Chemotherapy may be considered for patients who are not candidates for surgical resection; however, there currently is no established adjuvant chemotherapy for CCA [31]. The combination of gemcitabine and cisplatin remains the standard therapy for advanced CCA [32, 33]. No second line therapy has definitely demonstrated improved survival benefits [34]. Published studies for the treatment of CCA using a range of chemotherapeutic 
agents, alone and in combinations, during the past five years are summarized in Table 1 [35-68].

\section{Radiation}

There is limited evidence supporting the use of radiotherapy alone although some series demonstrate superior five-year survival, especially in perihilar CCA. Adjuvant radiotherapy may improve overall survival in patients undergoing resection for extrahepatic biliary tract carcinomas [69].

\section{Chemoradiotherapy}

Chemoradiation can prolong survival in CCA, particularly in the cases of hilar CCA and massforming intrahepatic CCA. Capecitabine is commonly used concurrently with radiotherapy and the available modalities for radiation include photons, intensity modulated radiation therapy (IMRT), proton beams and stereotactic radiation [70]; however, a randomized clinical trial in this regard are lacking.

Table 1: Recent studies treating cholangiocarcinoma with chemotherapeutic agents

\begin{tabular}{|c|c|c|c|c|c|}
\hline \multicolumn{6}{|c|}{ Phase 3 Studies } \\
\hline Author & Treatment & Patient Population & $\begin{array}{l}\text { Primary, } \\
\text { Secondary } \\
\text { Endpoints }\end{array}$ & Design & Outcome \\
\hline $\begin{array}{l}\text { Rogers et al. } \\
\text { [35] }\end{array}$ & $\begin{array}{l}\text { First line } \\
\text { gemcitabine }+ \\
\text { cisplatin }(n=36), \\
\text { gemcitabine }+ \\
\text { cisplatin + erlotinib } \\
(n=8) \text {, gemcitabine } \\
(n=1) \text { or other } \\
(n=11) .\end{array}$ & $\begin{array}{l}\text { Advanced intrahepatic } \\
\text { cholangiocarcinoma }\end{array}$ & $\begin{array}{l}\text { Primary: PFS } \\
\text { with second- } \\
\text { line systemic } \\
\text { treatments. } \\
\text { Secondary: OS } \\
\text { and disease } \\
\text { control rate } \\
\text { with second- } \\
\text { line systemic } \\
\text { regimens. }\end{array}$ & $\begin{array}{l}\text { Retrospective } \\
\text { chart review }\end{array}$ & $\begin{array}{l}\text { Median PFS of } 2.7 \text { months, } \\
50 \% \text { disease control rate, and } \\
\text { a potential survival benefit } \\
\text { with second-line systemic } \\
\text { therapy. No significant } \\
\text { difference between groups. }\end{array}$ \\
\hline Lee et al. [36] & $\begin{array}{l}\text { Gemcitabine and } \\
\text { oxaliplatin plus } \\
\text { erlotinib }(\mathrm{n}=135) \\
\text { vs. gemcitabine and } \\
\text { oxaliplatin alone } \\
(\mathrm{N}=133)\end{array}$ & $\begin{array}{l}\text { Metastatic biliary- } \\
\text { tract cancer } \\
\text { (cholangiocarcinoma, } \\
\text { gallbladder or ampulla } \\
\text { of Vater cancer) }\end{array}$ & Primary: PFS & $\begin{array}{l}\text { Open-label, } \\
\text { randomized }\end{array}$ & $\begin{array}{l}\text { Median PFS was } 4.2 \text { months } \\
\text { in the gemcitabine and } \\
\text { oxaliplatin group versus } 5.8 \\
\text { months in the gemcitabine } \\
\text { and oxaliplatin plus erlotinib } \\
\text { group (p = 0.087). }\end{array}$ \\
\hline \multicolumn{6}{|c|}{ Phase 2 Studies } \\
\hline $\begin{array}{l}\text { El-Khoueiry et } \\
\text { al. [37] }\end{array}$ & $\begin{array}{l}\text { Sorafenib } \\
(\mathrm{n}=36)\end{array}$ & $\begin{array}{l}\text { Metastatic or } \\
\text { unresectable biliary } \\
\text { cancers }\end{array}$ & $\begin{array}{l}\text { Primary: } \\
\text { Determine } \\
\text { the confirmed } \\
\text { objective } \\
\text { response rate in } \\
\text { patients treated } \\
\text { with sorafenib } \\
400 \text { mg twice } \\
\text { daily. } \\
\text { Secondary: } \\
\text { PFS, OS and AE } \\
\text { profile. }\end{array}$ & Open-label & $\begin{array}{l}\text { The study failed to meet } \\
\text { the primary objective was } \\
\text { terminated after the first } \\
\text { stage of accrual. A confirmed } \\
\text { response rate of o\% (o- } \\
\text { 11\%) was observed; } 39 \% \\
\text { demonstrated SD including } \\
\text { two with unconfirmed PR. } \\
\text { PFS was three months and OS } \\
\text { nine months. }\end{array}$ \\
\hline $\begin{array}{l}\text { Ben-Josef et } \\
\text { al. [38] }\end{array}$ & $\begin{array}{l}\text { Adjuvant } \\
\text { capecitabine and } \\
\text { gemcitabine followed } \\
\text { by radiotherapy } \\
\text { and concurrent } \\
\text { capecitabine } \\
(\mathrm{N}=79)\end{array}$ & $\begin{array}{l}\text { Extrahepatic } \\
\text { cholangiocarcinoma or } \\
\text { gallbladder carcinoma }\end{array}$ & $\begin{array}{l}\text { Primary: Two- } \\
\text { year survival } \\
\text { (overall and } \\
\text { after Ro or } \\
\text { R1 resection), } \\
\text { pattern of } \\
\text { relapse, and } \\
\text { toxicity }\end{array}$ & Open-label & $\begin{array}{l}\text { Two-year survival was } 65 \% \\
\text { (RO, 67\%; R1, 60\%). Median } \\
\text { overall survival was } 35 \text { months } \\
\text { (Ro, } 34 \text { months; R1, } 35 \\
\text { months). }\end{array}$ \\
\hline
\end{tabular}




\section{Table 1: (Continued)}

\begin{tabular}{|c|c|c|c|}
\hline $\begin{array}{l}\text { Malka et al. } \\
\text { [39] }\end{array}$ & $\begin{array}{l}\text { Gemcitabine and } \\
\text { oxaliplatin with }(\mathrm{N} \\
=76) \text { or without } \\
\text { cetuximab }(\mathrm{N}=74)\end{array}$ & $\begin{array}{l}\text { Non-resectable } \\
\text { or metastatic } \\
\text { cholangiocarcinoma, } \\
\text { gallbladder carcinoma, } \\
\text { or ampullary carcinoma }\end{array}$ & $\begin{array}{l}\text { Primary: } \\
\text { Proportion of } \\
\text { patients who } \\
\text { were PF at four } \\
\text { months }\end{array}$ \\
\hline
\end{tabular}

Denlinger et Bortezomib $(\mathrm{N}=20)$ Locally advanced al. [40] or metastatic Cholangiocarcinoma $(n=14)$ or gallbladder adenocarcinoma $(n=6)$

Park et al. [41] PDT with $(\mathrm{N}=21)$ or Unresectable hilar without $\mathrm{S}-1(\mathrm{~N}=22)$ cholangiocarcinoma

El-Khoueiry et Sorafenib and al. [42] erlotinib $(\mathrm{N}=34)$

Unresectable or metastatic. Cholangiocarcinoma or gallbladder carcinoma

Primary:

Objective response rate.

Primary: OS; Secondary: PFS, complications, re-intervention rate, QOL

Primary: PFS; Secondary: response probability, OS and toxicity

Primary: Five-month PFS; Secondary: ORR and OS

\section{Unresectable} or metastatic gemcitabine and irinotecan $(\mathrm{N}=35)$
Sohal et al.

[43]

$\begin{array}{ll}\text { Rubovszky et } & \text { Cetuximab, } \\ \text { al. [44] } & \begin{array}{l}\text { gemcitabine and } \\ \text { capecitabine }\end{array}\end{array}$

Borbath et al. Cetuximab and [45] gemcitabine $(\mathrm{N}=44)$

$$
\begin{aligned}
& \text { Intrahepatic } \\
& (\mathrm{n}=16) \text { and } \\
& \text { extrahepatic } \\
& \text { cholangiocarcinoma ( } \mathrm{n} \\
& =8) \text { and gallbladder } \\
& \text { cancer }(\mathrm{n}=10)
\end{aligned}
$$

Unresectable

cholangiocarcinoma
Primary: Assess

RR;

Secondary: PFS,

OS, AEs

Primary: PFS
Open-label, randomized

48 (63\%) treated with gemcitabine and oxaliplatin with cetuximab and 40 (54\%) treated with gemcitabine and oxaliplatin alone were progression-free at four months. Cetuximab did not enhance the activity of chemotherapy.

Open-label

One unconfirmed partial response. Trial discontinued early because of lack of confirmed partial responses.

Open-label, randomized

PDT plus S-1 showed higher one-year survival rate versus PDT alone (76.2\% versus $32 \%$, $\mathrm{p}=0.003$ ) and prolonged OS (median 17 months versus 8 months, $\mathrm{p}=0.005$. PDT plus S-1 showed prolonged PFS versus PDT alone (median 10 months versus 2 months $\mathrm{p}=$ 0.009.

Open-label

At fourth month patients had unconfirmed PR $(\mathrm{n}=6 ; 6 \%)$, SD ( $\mathrm{n}=10 ; 29 \%)$, $\mathrm{PD}(\mathrm{n}=18 ; 53 \%)$ and symptomatic deterioration leading to treatment discontinuation $(\mathrm{n}=1)$. Three patients were not evaluable. Median PFS was two months and four-month PFS was $29 \%$.

Open-label

After a medial of seven cycles, 28 evaluable patients had CR $(n=2)$, PR ( $n=9)$, SD $(n=15)$ for a disease-control rate of $74 \%$. Two patients underwent surgical resection. The fivemonth PFS was $69 \%$. The median PFS was 9.7 months and the median OS was 12.9 months.

Open-label

The ORR 17.6\% (two CR, four PR) and the CBR was $76.5 \%$. After a median of 15.4 months, the median PFS was 34.3 weeks and the median OS was 62.8 weeks.

At sixth month, PFS reached by $47 \%$. Median OS was 13.5 months. Nine patients (20.4\%) had PR and diseasecontrol rate was $79.5 \%$.

Primary: Improvement in six-month PFS6 from historical $57-77 \%$
Open-label

Six-month PFS was 51\%, median PFS was 6.5 months and OS was 14.4 months.
Advanced biliary
adenocarcinomas sorafenib $(\mathrm{N}=39)$ 
Table 1: (Continued)

\begin{tabular}{|c|c|c|c|c|c|}
\hline $\begin{array}{l}\text { Yamanaka et } \\
\text { al., [47] }\end{array}$ & $\begin{array}{l}\text { Gemcitabine } \\
\text { following surgical } \\
\text { resection }(n=40) \text { or } \\
\text { resection alone } \\
(n=158)\end{array}$ & $\begin{array}{l}\text { Biliary tract cancer } \\
\text { including gemcitabine- } \\
\text { treated patients with } \\
\text { extrahepatic } \\
(\mathrm{n}=18) \text { and } \\
\text { intrahepatic } \\
\text { cholangiocarcinoma } \\
(\mathrm{n}=15)\end{array}$ & Primary: OS & Open-label & $\begin{array}{l}\text { Among patients with } \\
\text { intrahepatic CCA, the } \\
\text { probability of two-year } \\
\text { survival in the gemcitabine } \\
\text { group was } 91.7 \% \text {, versus } 68.2 \\
\% \text { in the resection alone group } \\
(p=0.04) \text {. }\end{array}$ \\
\hline $\begin{array}{l}\text { Sasaki et al. } \\
{[48]}\end{array}$ & $\begin{array}{l}\text { Gemcitabine plus S-1 } \\
\text { versus gemcitabine } \\
\text { alone }\end{array}$ & $\begin{array}{l}\text { Advanced } \\
\text { cholangiocarcinoma or } \\
\text { gallbladder cancer } \\
(\mathrm{N}=62)\end{array}$ & Primary: RR & $\begin{array}{l}\text { Open-label, } \\
\text { randomized }\end{array}$ & $\begin{array}{l}\text { RR for combination therapy } \\
\text { was } 20 \% \text { versus } 9.4 \% \text { for } \\
\text { monotherapy; however, the } \\
\text { median time-to-progression } \\
\text { and OS were nearly the same } \\
\text { ( } 5.6 \text { versus } 4.3 \text { months; } 8.9 \\
\text { versus } 9.2 \text { months). }\end{array}$ \\
\hline $\begin{array}{l}\text { Jensen et al. } \\
\text { [49] }\end{array}$ & $\begin{array}{l}\text { Panitumumab } \\
(\mathrm{N}=46)\end{array}$ & $\begin{array}{l}\text { Non-resectable biliary } \\
\text { tract cancer }\end{array}$ & $\begin{array}{l}\text { Primary: Patients } \\
\text { alive without } \\
\text { progression at } \\
\text { sixth month. } \\
\text { Secondary: } \\
\text { Median PFS, RR, } \\
\text { median OS }\end{array}$ & & $\begin{array}{l}\text { Among evaluable patients (n } \\
=42), \text { PFS at } 6 \text { months was } \\
31(74 \%), 42 \text { had measurable } \\
\text { disease. RR was } 33 \% \text { and } \\
\text { disease control rate } 86 \% \text {. } \\
\text { Median PFS was } 8.3 \text { months } \\
\text { and median OS was } 10.0 \\
\text { months. }\end{array}$ \\
\hline $\begin{array}{l}\text { Roth et al. } \\
\text { [50] }\end{array}$ & $\begin{array}{l}\text { Imatinib mesylate } \\
(\mathrm{N}=9)\end{array}$ & $\begin{array}{l}\text { Unresectable } \\
\text { advanced or metastatic } \\
\text { intrahepatic and } \\
\text { extrahepatic } \\
\text { cholangiocarcinoma or } \\
\text { gallbladder carcinoma } \\
\text { unresponsive to prior } \\
\text { treatment }\end{array}$ & $\begin{array}{l}\text { Primary: CR, } \\
\text { PR and PFS. } \\
\text { Secondary: PK, } \\
\text { SD, TTP and OS }\end{array}$ & Open-label & $\begin{array}{l}\text { The study was stopped early } \\
\text { due to poor recruitment } \\
\text { but five patients treated for } \\
\text { at least three months. Five } \\
\text { patients experienced PD with } \\
\text { a median TTP of } 79 \text { days } \\
\text { (range, } 38-116 \text { days). Median } \\
\text { OS was } 4.9 \text { months (range, } \\
1.5-42.8 \text { months). }\end{array}$ \\
\hline $\begin{array}{l}\text { Kemeny et al. } \\
\text { [51] }\end{array}$ & $\begin{array}{l}\text { Hepatic arterial } \\
\text { infusion of } \\
\text { floxuridine and } \\
\text { dexamethasone plus } \\
\text { bevacizumab } \\
(\mathrm{N}=22)\end{array}$ & $\begin{array}{l}\text { Unresectable } \\
\text { intrahepatic } \\
\text { cholangiocarcinoma } \\
\text { or hepatocellular } \\
\text { carcinoma }\end{array}$ & $\begin{array}{l}\text { Primary: Effect } \\
\text { of adding } \\
\text { bevacizumab on } \\
\text { PFS. Secondary: } \\
\text { RR, OS and } \\
\text { conversion to } \\
\text { resectability. }\end{array}$ & Open-label & $\begin{array}{l}\text { Seven }(31.8 \%) \text { had PR and } \\
15(68.2 \%) \text { had SD. Median } \\
\text { survival was } 31.1 \text { months, } \\
\text { PFS } 8.45 \text { months and hepatic } \\
\text { PFS } 11.3 \text { months. The trial } \\
\text { was terminated early due to } \\
\text { increased biliary toxicity. }\end{array}$ \\
\hline $\begin{array}{l}\text { Iqbal et al. } \\
\text { [52] }\end{array}$ & $\begin{array}{l}\text { Gemcitabine and } \\
\text { capecitabine } \\
(\mathrm{N}=57)\end{array}$ & $\begin{array}{l}\text { Gallbladder cancer or } \\
\text { cholangiocarcinoma }\end{array}$ & $\begin{array}{l}\text { Primary: RR } \\
\text { (CR and PR). } \\
\text { Secondary: OS } \\
\text { and toxicity. }\end{array}$ & Open-label & $\begin{array}{l}\text { There were } 52 \\
\text { evaluable patients with } \\
\text { cholangiocarcinoma } \\
\text { (n=35) and gallbladder } \\
\text { cancer ( } \mathrm{n}=17 \text { ). There were } \\
\text { seven confirmed PR, six } \\
\text { unconfirmed PR, } 12 \text { SD. The } \\
\text { six-month OS was } 55 \% \text { and } \\
\text { median survival was seven } \\
\text { months. }\end{array}$ \\
\hline Oh et al. [53] & $\begin{array}{l}\text { Gemcitabine } \\
(\mathrm{N}=32)\end{array}$ & $\begin{array}{l}\text { Intra-hepatic } \\
\text { cholangiocarcinoma } \\
(\mathrm{n}=16) \text {, gallbladder } \\
\text { cancer }(\mathrm{n}=12) \text {, } \\
\text { and extrahepatic } \\
\text { cholangiocarcinoma } \\
(\mathrm{n}=4) \text { with disease } \\
\text { progression after } \\
\text { 5-fluorouracil-based } \\
\text { palliative chemotherapy }\end{array}$ & $\begin{array}{l}\text { Primary: Efficacy } \\
\text { and safety of } \\
\text { gemcitabine as } \\
\text { second-line }\end{array}$ & Open-label & $\begin{array}{l}\text { Among evaluable patients } \\
\text { ( } \mathrm{n}=29 \text { ), two achieved PR with } \\
\text { an overall response rate of } \\
6.9 \% \text {, six had SD, } 21 \text { showed } \\
\text { disease progression. The } \\
\text { median follow-up duration } \\
\text { was } 23.2 \text { months. The median } \\
\text { TTP was } 1.6 \text { months and } \\
\text { the median OS time was } 4.1 \\
\text { months. }\end{array}$ \\
\hline
\end{tabular}


Table 1: (Continued) Bekaii-Saab et Selumetinib $(\mathrm{N}=28)$
al. [54]

\section{Phase 1/2 Studies}

Iwahashi et al. Valproic acid (VPA) [55] plus S-1 $(\mathrm{N}=12)$

\section{Phase 1 Studies}

Costello et al. Everolimus plus [56]

Suder et al. Afatinib plus [57]

Isakoff et al. Bosutinib plus [58]

Koido et al. Gemcitabine plus Pancreatic ductal [59]

Pant et al. Tivantinib and [6o] escalation phase),

Hickey et al. [61]

Kobrinsky et al. [62] gemcitabine (Cohort 1) and cisplatin (Cohort 2) paclitaxel $(\mathrm{N}=16)$ capecitabine $(\mathrm{N}=$ 32)

Locally advanced, treatment-resistant metastatic cancer $(\mathrm{N}=32)$ including cholangiocarcinoma ( $\mathrm{n}=1$ ) dendritic cells pulsed with a mixture of three types of WT1 peptides, including both MHC class I and II-restricted epitopes gemcitabine, $\mathrm{N}=$ 74 ( $\mathrm{n}=29$, dose ( $n=45$, expansion phase)

\section{Radioembolization (yttrium-90) and} capecitabine $(\mathrm{N}=16)$ Bortezomib with

Advanced pancreatobiliary tract cancers

Cholangiocarcinoma or gallbladder carcinoma (Cohort 3; $\mathrm{N}=10$ )

\section{Advanced solid} tumors including cholangiocarcinoma adenocarcinoma $(n=10)$, intrahepatic cholangiocarcinoma ( $\mathrm{n}=1$ )

Advanced-stage solid tumors including cholangiocarcinoma $(\mathrm{n}=8)$

Cholangiocarcinoma or metastases confined to the liver

Solid tumors oxaliplatin $(\mathrm{N}=30)$

\author{
Primary: ORR \\ (CR and PR). \\ Secondary: \\ Toxicity, OS, \\ PFS.
}

\section{Primary:}

Effectiveness

of combination

therapy with VPA

and S-1

\section{Primary: MTD}

Open-

label, dose escalation

Primary: MTD of afatinib plus paclitaxel. Secondary: safety, PK, antitumor activity

Primary: MTD, safety and efficacy

Primary: safety and toxicity

Primary: safety, tolerability and establish a phase 2 dose of tivantinib and gemcitabine

Primary: MTD

Primary: MTD
Openlabel, dose escalation

Open-

label, dose escalation

Open-label

Open-label

The overall disease control rate $(\mathrm{CR}+\mathrm{PR}+\mathrm{SD})$ was $66 \%$ (37 of 56). The median PFS was 129 days. PR was observed in 10 patients including one with cholangiocarcinoma.

Open-label

Openlabel, dose escalation was observed in one patient with cholangiocarcinoma.

None of the patients with pancreatic cancer or a response or SD.

WT1-specific DTH-positive improved OS and PFS vs. negative controls. All three OS of 717 days.

Criteria for establishing yttrium-90 MTD were not met. four had PR including one ampulla of Vater carcinoma
Three patients had OR including confirmed PR $(\mathrm{n}=3)$ and unconfirmed CR $(n=1) 17$ patients $(68 \%)$ had SD including 11 (44\%) with SD duration $\geq 16$ weeks and three (12\%) with duration of more than one year.

Median PFS was 3.7 months and median OS was 9.8 months.

Among patients in Cohort 3, six had stable disease and four had progressive disease.

A confirmed partial response cholangiocarcinoma achieved patients showed significantly patients with PDA with strong DTH reactions had a median

Among 25 evaluable patients, and one cholangiocarcinoma. 
Table 1: (Continued)

\begin{tabular}{|c|c|c|c|c|c|}
\hline Pant et al. [63] & $\mathrm{ME}-143(\mathrm{~N}=18)$ & $\begin{array}{l}\text { Advanced solid } \\
\text { tumors including } \\
\text { cholangiocarcinoma } \\
(\mathrm{n}=2)\end{array}$ & Primary: MTD & $\begin{array}{l}\text { Open- } \\
\text { label, dose } \\
\text { escalation }\end{array}$ & $\begin{array}{l}\text { SD achieved in three } \\
\text { patients including one with } \\
\text { cholangiocarcinoma. }\end{array}$ \\
\hline $\begin{array}{l}\text { Plummer et al. } \\
\text { [64] }\end{array}$ & $\begin{array}{l}\text { Pazopanib plus } \\
\text { gemcitabine }(\mathrm{N}=22)\end{array}$ & Advanced solid tumors & Primary: MTD & $\begin{array}{l}\text { Open- } \\
\text { label, dose } \\
\text { escalation }\end{array}$ & $\begin{array}{l}\text { Prolonged disease stabilization } \\
\text { ( }>12 \text { cycles) was reported in } \\
\text { three patients including one } \\
\text { with cholangiocarcinoma. }\end{array}$ \\
\hline $\begin{array}{l}\text { Kurzrock et al. } \\
\text { [65] }\end{array}$ & $\mathrm{EZN}-2208(\mathrm{~N}=39)$ & $\begin{array}{l}\text { Metastatic or advanced } \\
\text { malignancies including } \\
\text { cholangiocarcinoma } \\
(\mathrm{n}=1)\end{array}$ & Primary: MTD & $\begin{array}{l}\text { Open- } \\
\text { label, dose } \\
\text { escalation }\end{array}$ & $\begin{array}{l}\text { The patient with } \\
\text { cholangiocarcinoma had } \\
\text { a transient } 32 \% \text { tumor } \\
\text { regression in target lesions. }\end{array}$ \\
\hline $\begin{array}{l}\text { Konner et al. } \\
{[66]}\end{array}$ & $\begin{array}{l}\text { KOS-862 } \\
\text { (Epothilone D) } \\
(\mathrm{N}=32)\end{array}$ & $\begin{array}{l}\text { Advanced solid tumors } \\
\text { or lymphoma }\end{array}$ & Primary: MTD & Open-label & $\begin{array}{l}\text { Stable disease }>3 \text { months } \\
\text { was achieved by five } \\
\text { patients including one with } \\
\text { cholangiocarcinoma }\end{array}$ \\
\hline $\begin{array}{l}\text { Gore et al. } \\
{[67]}\end{array}$ & $\begin{array}{l}\text { Trabectedin plus } \\
\text { capecitabine } \\
(\mathrm{N}=40)\end{array}$ & $\begin{array}{l}\text { Advanced malignancies } \\
\text { refractory to standard } \\
\text { therapy }\end{array}$ & Primary: MTD & Open-label & $\begin{array}{l}\text { One patient with } \\
\text { cholangiocarcinoma achieved } \\
\text { a sustained PR }\end{array}$ \\
\hline $\begin{array}{l}\text { Katayose et al. } \\
{[68]}\end{array}$ & $\begin{array}{l}\text { Neoadjuvant } \\
\text { chemoradiation with } \\
\text { gemcitabine and } \\
\text { surgical resection } \\
(\mathrm{N}=12)\end{array}$ & $\begin{array}{l}\text { Resectable } \\
\text { cholangiocarcinoma }\end{array}$ & Primary: MTD & $\begin{array}{l}\text { Open- } \\
\text { label, dose } \\
\text { escalation }\end{array}$ & $\begin{array}{l}600 \mathrm{mg} / \mathrm{m}^{2} \text { was determined } \\
\text { to be the MTD and } \\
\text { recommended dose for } \\
\text { gemcitabine in a phase } 2 \\
\text { study. }\end{array}$ \\
\hline
\end{tabular}

AE: Adverse Event, CBR: Clinical Benefit Rate, CR: Complete Remission, MHC: Major Histocompatibility Complex, MTD: Maximum Tolerated Dose, ORR: Overall Response Rate, OS: Overall Survival, PD: Progressive Disease, PDT: Photodynamic Therapy, PK: Pharmacokinetics, PR: Partial Response, PSF: Progression-Free Survival, QOL: Quality of Life, RR: Response Rate, SD: Stable Disease, TTP: Time to Tumor Progression, WT1: Wilms' tumor 1.

Afatinib: Irreversible ErbB family blocker

Bosutinib: competitive Src/Abl tyrosine kinase inhibitor

S-1: Oral fluoropyrimidine derivative consisting of 5-fluorouracil

Tivantinib: Non-adenosine triphosphate competitive, selective c-MET inhibitor
Panitumumab: Monoclonal anti-EGFR antibody, with gemcitabine and irinotecan

ME-143: Second-generation tumor-specific NADH oxidase inhibitor

EZN-2208: Polyethylene glycol conjugate of $\mathrm{SN}_{3} 8$, the active moiety of irinotecan

\section{Palliative care for unresectable Cholangiocarcinoma}

Nearly half of patients with CCA have unresectable disease and are candidates for palliative care [71]. Endoscopic biliary drainage is the gold standard treatment in advanced or inoperable hilar cholangiocarcinoma [72]. The main goal is to provide biliary drainage with longterm relief from pruritus, cholangitis, pain and jaundice [73]. In patients with inoperable disease, drainage of $50 \%$ or more of the liver parenchyma via stenting can improve patient survival [2]. The management of biliary obstruction with stents is obligatory in perihilar CCA [2]. This may be done endoscopically or percutaneously [74]. Possible complications to stenting include infections [75] and stent migration causing injury [76]. Other palliative measures may include oral nutritional supplements or parenteral nutritional support for patients with cachexia [77].

\section{EMERGING THERAPIES}

\section{Adjuvant therapy}

A recent phase 2 trial demonstrated gemcitabine and capecitabine followed by chemoradiotherapy with concurrent capecitabine is an effective and promising adjuvant regimen in extrahepatic cholangiocarcinoma and also gallbladder carcinoma [38]. Subjects with extrahepatic cholangiocarcinoma or gallbladder carcinoma and radical resection, stage pT2-4 or $\mathrm{N}+$ or positive resection margins, Mo, and performance status $\mathrm{O}$ to 1 were treated with four cycles of IV gemcitabine 1,000 $\mathrm{mg} / \mathrm{m}^{2}$ on day- 1 and day- 8 and daily capecitabine 1,500 $\mathrm{mg} / \mathrm{m}^{2}$ on days $1-14$ followed by concurrent capecitabine $1,330 \mathrm{mg} / \mathrm{m}^{2}$ daily and radiotherapy. With 80 evaluable patients, results would be promising if two-year survival $95 \%$ CI were $>45 \%$ and Ro and R 1 survival estimates were $\geq 65 \%$ and $45 \%$, respectively. Among evaluable subjects 
( $\mathrm{n}=79$ ), the median overall survival was 35 months and disease-free survival at second year was $52 \%$. Local, distant, and combined relapse occurred in 14,24 , and 9 patients, respectively.

The superiority of cisplatin and gemcitabine chemotherapy over gemcitabine alone for treating advanced biliary tract cancer (ABC) was demonstrated in two randomized trials (ABCo2 and BT-22 studies) [78]. Combined data from these trials was used to investigate the derived neutrophil-to-lymphocyte ratio which may predict clinical outcomes in some solid tumors including ABC. A total of 462 individual patient records were analyzed, 328 with baseline derived neutrophil-tolymphocyte ratio $<3$ and $134 \geq 3$. All surviving patients ( $\mathrm{n}=19$ ) had a derived neutrophil-to-lymphocyte ratio $<3$. There was strong evidence that derived neutrophilto-lymphocyte ratio was closely associated with both overall survival (hazard ratio 1.62; 95\% CI 1.32-2.01) and progression-free survival (hazard ratio 1.40; $95 \%$ CI 1.13-1.72). There was significant evidence of an association between low baseline derived neutrophil-tolymphocyte ratio and long-term survival on a cisplatin and gemcitabine regimen.

\section{Immunotherapy}

Advances in cancer immunotherapy have encouraged the development of new treatment options. This type of treatment strengthens the patient's immune system by priming it against tumor-specific antigens. Immunotherapy is based on the observation that tumor infiltration by the cellular mediators of the adaptive immune response such as $\mathrm{CD} 8+$ and $\mathrm{CD} 4+$ cells is generally correlated with improved outcomes in biliary tract cancers $[79,80]$. Similarly, patients with higher total regulatory $\mathrm{T}$ lymphocyte counts have a significantly better prognosis when compared with those patients whose tumor tissues showed lower regulatory T-lymphocyte counts [81]. Such treatments are more selective against malignant cells and generally less toxic than traditional chemotherapy [82]. Conversely, antibodies against glycoprotein 2 are associated with more severe phenotype and poor survival due to cholangiocarcinoma [83].

Immunotherapy has recently made great advances in the field of oncology, such as the programmed death ligand 1 (PD-L1) inhibitors pembrolizumab for nonsmall cell lung cancer [84] and nivolumab for metastatic melanoma [85], non-small cell lung cancer [86] and renal cell carcinoma [87]. Elevated serum PD-L1 in patients with cholangiocarcinoma have been shown to have poorer overall survival [88], suggesting these checkpoint inhibitors may also be beneficial for this patient population. In one case report, a patient with extrahepatic cholangiocarcinoma demonstrated a strong and durable response to the immune checkpoint inhibitor pembrolizumab [89].

\section{Orthotopic liver transplantation}

Several ongoing clinical trials are assessing new methods for OLT. One prospective, open-label, randomized, study will compare the use of capecitabine and radiotherapy or neoadjuvant radiochemotherapy and liver transplantation versus conventional liver and bile duct resection (ClinicalTrials.gov Identifier: NCTo2232932). An observational study is designed to validate results of a previous study performed at the Mayo Clinic [90] where patients were treated with combination chemotherapy and radiation and maintained on oral capecitabine until they can receive a liver transplant (ClinicalTrials.gov Identifier: NCToo301379).

\section{Tumor microenvironment}

Similar to other treatment-resistant cancers, intrahepatic CCA is characterized by the growth of fibrous or connective tissue, or desmoplasia, around the tumor [91]. This desmoplasia progresses during disease progression and includes stromal fibroblasts, immune cells, and excessive deposition of a complex extracellular matrix which is often rich in hyaluronan [92]. Proliferation of this tumor microenvironment forms an impediment to treating solid tumors such as CCA by increasing interstitial fluid pressure which compresses the surrounding vasculature and promotes tumor progression and the metastatic potential of cancer cells [93] and reduces the beneficial effects of systemic chemotherapeutic agents [91, 94]. As hyaluronan is a major component of the tumor microenvironment, reducing tumor hyaluronan with PEGylated human recombinant hyaluronidase decreased interstitial fluid pressure, improved vascular perfusion and increased the effectiveness of docetaxel and liposomal doxorubicin in a murine model of prostate cancer [94].

Large amounts of hyaluronan also exist in the tumor microenvironment of intrahepatic CCA [95] and may represent a target for future therapies [96]. A phase 1 study assessed the efficacy of PEGylated human recombinant hyaluronidase in combination with gemcitabine in patients with untreated stage IV metastatic pancreatic ductal adenocarcinoma [97]. Among patients evaluated for pretreatment tissue hyaluronan levels, median progression-free survival and overall survival rates were 7.2 and 13.0 months, respectively, for patients with high hyaluronan levels versus and 3.5 and 5.7 months for patients with low hyaluronan levels.

\section{Molecular targeted agents}

Intrahepatic CCA exists as a range of genetic subtypes [98] with varying sensitivity to chemotherapeutics and molecular targeted agents [99]. Genetic studies of biliary tumors have identified known growth factor gene mutations [100, 101] and signaling pathways [102] that control tumor growth and survival. Target-specific monoclonal antibodies and small molecule inhibitors directed against the signaling pathways that promote 
the growth and spread of cholangiocarcinoma are being developed [103]. Such targeted therapies are showing promise for treatment-resistant CCA.

Recently identified gene mutations include epidermal growth factor receptor (EGFR), Kirsten rat sarcoma viral oncogene homolog (KRAS), v-raf murine sarcoma viral oncogene homolog (BRAF) and tumor protein p53 (TP53). Other novel mutations include isocitrate dehydrogenase (IDH), BRCA1-associated protein 1 (BAP1) and AT-rich interactive domain-containing protein $1 \mathrm{~A}$ (ARID1A), and novel fusions such as fibroblast growth factor receptor 2 (FGFR2) and ROS proto-oncogene 1 (ROS1) [100].

Several ongoing clinical trials using targeted therapy for cholangiocarcinoma are described in Table 2. In one example, folic acid was used as a targeting agent in CCA cells expressing folic acid receptors [104]. When 5-fluorouracil and folic acid were linked to gold nanoparticles, its cytotoxicity was correlated with folic acid receptor expression, suggesting the use of folic acid as a targeted therapy.

\section{Mutation profiling}

Significant genetic differences between intrahepatic and extrahepatic CCA have been identified which may have implications for treatment and outcomes [105]. In one study, 75 samples undergoing next generation sequencing were from patients with intrahepatic ( $\mathrm{n}=$ 55) and extrahepatic CCA $(n=20)$ [106]. Significant differences were found in these two groups with respect to the nature and frequency of the genetic aberrations. These are summarized in Table 3. IDH1 and DNA repair gene alterations occurred more frequently in intrahepatic CCA, while more ERBB2 genetic abnormalities occurred

Table 2: Clinical trials of molecular targeted agents for cholangiocarcinoma

\begin{tabular}{|c|c|c|c|c|}
\hline Target & Study title & $\begin{array}{l}\text { ClinicalTrials. } \\
\text { gov Identifier }\end{array}$ & Sponsor & Outcome measures \\
\hline EGFR & $\begin{array}{l}\text { A phase II, single arm study of } \\
\text { BGJ398 in patients with advanced } \\
\text { cholangiocarcinoma }\end{array}$ & NCT02150967 & $\begin{array}{l}\text { Novartis } \\
\text { Pharmaceuticals }\end{array}$ & $\begin{array}{l}\text { Primary: ORR. Secondary: } \\
\text { OS, PFS, OR, DCR, AEs/ } \\
\text { SAEs, PK }\end{array}$ \\
\hline VEGF & $\begin{array}{l}\text { A phase } 2 \text { trial of regorafenib as } \\
\text { a single agent in advanced and } \\
\text { metastatic biliary tract carcinoma/ } \\
\text { cholangiocarcinoma patients who } \\
\text { have failed first-line chemotherapy }\end{array}$ & NCTo2053376 & $\begin{array}{l}\text { University of } \\
\text { Pittsburgh }\end{array}$ & $\begin{array}{l}\text { Primary: PFS. Secondary: } \\
\text { OR, OS, changes in } \\
\text { biomarkers (CA19-9 and } \\
\text { CEA) }\end{array}$ \\
\hline FGFR & $\begin{array}{l}\text { Open-label, dose-escalation study } \\
\text { of INCBo54828 in subjects with } \\
\text { advanced malignancies }\end{array}$ & NCTo2393248 & Incyte Corporation & $\begin{array}{l}\text { Primary: MTD } \\
\text { Secondary: ORR (RECIST), } \\
\text { PK }\end{array}$ \\
\hline BRAF & $\begin{array}{l}\text { Afatinib dimaleate and capecitabine } \\
\text { in treating patients with advanced } \\
\text { refractory solid tumors, pancreatic } \\
\text { cancer or biliary cancer }\end{array}$ & NCTo2451553 & $\begin{array}{l}\text { University of } \\
\text { Washington }\end{array}$ & $\begin{array}{l}\text { Primary: AEs, DLT, MTD } \\
\text { (CTCAE v4.o), PFS, RP2D. } \\
\text { Secondary: biomarker profile } \\
\text { (EGFR, HER2 gene, etc.), } \\
\text { DOR, SD, OS, RR (RECIST } \\
\text { v1.1), TTP }\end{array}$ \\
\hline PD-1/ PDL-1 & $\begin{array}{l}\text { Study of pembrolizumab (MK- } \\
3475 \text { ) in participants with advanced } \\
\text { solid tumors (MK-3475-158/ } \\
\text { KEYNOTE-158) }\end{array}$ & NCTo2628067 & $\begin{array}{l}\text { Merck Sharp \& Dohme } \\
\text { Corp. }\end{array}$ & Primary: ORR \\
\hline $\begin{array}{l}\text { Tyrosine } \\
\text { kinase }\end{array}$ & $\begin{array}{l}\text { Basket study of entrectinib (RXDX- } \\
\text { 101) for the treatment of patients with } \\
\text { solid tumors harboring NTRK1/2/3, } \\
\text { ROS1, or ALK gene rearrangements } \\
\text { (fusions) (STARTRK-2) }\end{array}$ & NCTo2568267 & Ignyta, Inc. & $\begin{array}{l}\text { Primary: ORR (RECIST v1.1) } \\
\text { Secondary: DOR, TTR, CBR, } \\
\text { intracranial tumor response, } \\
\text { CNS PFS, PFS, OS }\end{array}$ \\
\hline IDH1 & $\begin{array}{l}\text { Study of orally administered AG- } \\
120 \text { in subjects with advanced solid } \\
\text { tumors, including glioma, with an } \\
\text { IDH1 mutation }\end{array}$ & NCT02073994 & $\begin{array}{l}\text { Agios Pharmaceuticals, } \\
\text { Inc. }\end{array}$ & $\begin{array}{l}\text { Primary: AEs, MTD. } \\
\text { Secondary: DLTs, PK, PD, } \\
\text { clinical activity (RECIST v1.1) }\end{array}$ \\
\hline
\end{tabular}

aStudies can be reviewed at: https://clinicaltrials.gov

AEs: Adverse events, AG-120: IDH1 mutant inhibitor, CA19-9: Cancer antigen 19-9, CEA: Carcinoembryonic antigen,

CBR: Clinical benefit rate, DCR: Disease control rate (proportion of patients with a best overall response of CR or PR or SD), DOR: Duration of response, EGFR: Epidermal growth factor receptor, FGFR: Fibroblast growth factor receptors, IDH1: Isocitrate dehydrogenase-1, PD: Pharmacodynamics, PK: Pharmacokinetics, ORR: Objective response rate, RECIST: Response Evaluation Criteria in Solid Tumors, RP2D: Recommended phase 2 dose, RR: Response rate, PD-1 / PDL-1: Programmed cell death protein 1 / programmed death ligand 1, SAEs: Serious adverse events, SD: Stable disease, TTP: Time to progression, VEGF: Vascular endothelial growth factor. 
Table 3: Genetic differences between Intrahepatic and extrahepatic cholangiocarcinoma

Abnormality Intrahepatic cholangiocarcinoma
Extrahepatic cholangiocarcinoma

\section{Genes}

TP53

$16(29.1 \%)$

9 (45\%)

KRAS

13 (23.6\%)

8 (40\%)

ARID1A

11 (20\%)

1 (5\%)

ERBB2

$1(1.8 \%)$

$5(20 \%)$

PBRM1

6 (10.9\%)

BAP1

$5(9.1 \%)$

2 (10\%)

FBXW7

$3(5.5 \%)$

3 (15\%)

SMAD4

2 (3.6\%)

$5(25 \%)$

IDH

$13(23.6 \%)$

o (o\%)

Pathways

MAP-ERK

$19(34.5 \%)$

$11(55 \%)$

mTOR

$14(25.5 \%)$

$8(40 \%)$

DNA Repair

$9(16.4 \%)$

8 (40\%)

FGF Pathway

$7(12.7 \%)$

1 (5\%)

18 (32.7\%)

Chromatin Modification

3 (15\%)

Modified from Churi et al., 2014.

among extrahepatic. In intrahepatic CCA, KRAS, TP53 or MAPK/mTOR genetic abnormalities were significantly associated with a worse prognosis while FGFR genetic abnormalities were correlated with slow-growing tumors. Based on these mutational profiles, many patients were referred to phase 1 or 2 clinical trials with targeted therapy for enrollment [106].

\section{Promoting the advancement of drug development}

The cholangiocarcinoma Foundation (CF) was founded in 2006 with the mission of finding a cure and improving the quality of life for those affected by cholangiocarcinoma. In recent years, the $\mathrm{CF}$ has promoted the development of new treatments for CCA by sponsoring an annual conference where interested individuals come together to learn more about the latest advances in bile duct cancer research, treatment and care. Recognizing the unmet medical need for treating CCA, the $\mathrm{CF}$ is proactively working with the pharmaceutical and biotechnology companies to accelerate drug development by sponsoring an Industry Night at the annual conference. Representatives from industry are invited to present cholangiocarcinoma clinical trial concepts to a panel of more than 20 global biliary cancer experts. The objective is to accelerate drug development by providing immediate feedback at a considerable cost-savings. To date, this program has been very well received and will hopefully serve as a model for advancing the treatment of other challenging disorders.

\section{CONCLUSION}

Cholangiocarcinoma has long been a challenging disease with poor outcomes. The development of emerging new therapies is currently underway that may improve the treatment outcomes of this devastating disease. In addition to providing research grants, disease foundations have an opportunity to work co-operatively with the pharmaceutical and biotechnology companies to advance emerging new therapies.

$$
* * * * * * * * *
$$

\section{Author Contributions}

Sean Turbeville - Substantial contributions to conception and design, Acquisition of data, Analysis and interpretation of data, Drafting of article, Revising it critically for important intellectual content, Final approval of the version to be published

Carl S. Hornfeldt - Substantial contributions to conception and design, Acquisition of data, Analysis and interpretation of data, Drafting of article, Revising it critically for important intellectual content, Final approval of the version to be published

Milind Javle-Substantial contributions to conception and design, Acquisition of data, Analysis and interpretation of data, Drafting of article, Revising it critically for important intellectual content, Final approval of the version to be published

Eric Tran - Substantial contributions to conception and design, Acquisition of data, Analysis and interpretation of data, Drafting of article, Revising it critically for important 
intellectual content, Final approval of the version to be published

Marion Schwartz - Substantial contributions to conception and design, Acquisition of data, Analysis and interpretation of data, Drafting of article, Revising it critically for important intellectual content, Final approval of the version to be published

\section{Guarantor}

The corresponding author is the guarantor of submission.

\section{Conflict of Interest}

Authors declare no conflict of interest.

\section{Copyright}

(C) Sean Turbeville et al. This article is distributed under the terms of Creative Commons Attribution License which permits unrestricted use, distribution and reproduction in any medium provided the original author(s) and original publisher are properly credited. Please see the copyright policy on the journal website for more information.

\section{REFERENCES}

1. Bergquist A, von Seth E. Epidemiology of cholangiocarcinoma. Best Pract Res Clin Gastroenterol 2015 Apr;29(2):221-32.

2. Razumilava N, Gores GJ. Cholangiocarcinoma. Lancet 2014 Jun 21;383(9935):2168-79.

3. Rizvi S, Gores GJ. Pathogenesis, diagnosis, and management of cholangiocarcinoma. Gastroenterology 2013 Dec;145(6):1215-29.

4. Rizvi S, Gores GJ. Current diagnostic and management options in perihilar cholangiocarcinoma. Digestion 2014;89(3):216-24.

5. Khan SA, Toledano MB, Taylor-Robinson SD. Epidemiology, risk factors, and pathogenesis of cholangiocarcinoma. HPB (Oxford) 2008;10(2):7782.

6. DeOliveira ML, Cunningham SC, Cameron JL, et al. Cholangiocarcinoma: Thirty-one-year experience with 564 patients at a single institution. Ann Surg 2007 May;245(5):755-62.

7. Mavros MN, Economopoulos KP, Alexiou VG, Pawlik TM. Treatment and prognosis for patients With intrahepatic cholangiocarcinoma: Systematic review and meta-analysis. JAMA Surg 2014 Jun;149(6):56574 .

8. Rizvi S, Gores GJ. Molecular pathogenesis of cholangiocarcinoma. Dig Dis 2014;32(5):564-9.

9. Razumilava N, Gores GJ, Lindor KD. Cancer surveillance in patients with primary sclerosing cholangitis. Hepatology 2011 Nov;54(5):1842-52.

10. Palmer WC, Patel T. Are common factors involved in the pathogenesis of primary liver cancers? A meta-analysis of risk factors for intrahepatic cholangiocarcinoma. J Hepatol 2012 Jul;57(1):69-76.

11. Ren HB, Yu T, Liu C, Li YQ. Diabetes mellitus and increased risk of biliary tract cancer: Systematic review and meta-analysis. Cancer Causes Control 2011 Jun;22(6):837-47.
12. Lim JH. Liver flukes: The malady neglected. Korean J Radiol 2011 May-Jun;12(3):269-79.

13. Sripa B, Bethony JM, Sithithaworn $P$, et al. Opisthorchiasis and opisthorchis-associated cholangiocarcinoma in Thailand and Laos. Acta Trop 2011 Sep;120 Suppl 1:S158-68.

14. Rustagi T, Dasanu CA. Risk factors for gallbladder cancer and cholangiocarcinoma: Similarities, differences and updates. J Gastrointest Cancer 2012 Jun;43(2):137-47.

15. Li M, Li J, Li P, et al. Hepatitis B virus infection increases the risk of cholangiocarcinoma: A metaanalysis and systematic review. J Gastroenterol Hepatol 2012 Oct;27(10):1561-8.

16. Li JS, Han TJ, Jing N, et al. Obesity and the risk of cholangiocarcinoma: A meta-analysis. Tumor Biol 2014 Jul;35(7):6831-8.

17. Kim HJ, Kim JS, Joo MK, et al. Hepatolithiasis and intrahepatic cholangiocarcinoma: A review. World J Gastroenterol 2015 Dec 28;21(48):13418-31.

18. Ghouri YA, Mian I, Blechacz B. Cancer review: Cholangiocarcinoma. J Carcinog 2015 Feb 23;14:1.

19. SeereeP,Pearngam $P$, KumkateS,JanvilisriT.Anomics perspective on molecular biomarkers for diagnosis, prognosis, and therapeutics of cholangiocarcinoma. Int J Genomics 2015;2015:179528.

20. Vasilieva LE, Papadhimitriou SI, Dourakis SP. Modern diagnostic approaches to cholangiocarcinoma. Hepatobiliary Pancreat Dis Int 2012 Aug 15;11(4):34959.

21. Navaneethan U, Njei B, Venkatesh PG, Vargo JJ, Parsi MA. Fluorescence in situ hybridization for diagnosis of cholangiocarcinoma in primary sclerosing cholangitis: A systematic review and meta-analysis. Gastrointest Endosc 2014 Jun;79(6):943-50.e3.

22. Lok T, Chen L, Lin F, Wang HL. Immunohistochemical distinction between intrahepatic cholangiocarcinoma and pancreatic ductal adenocarcinoma. Hum Pathol 2014 Feb;45(2):394-400.

23. Navaneethan U, Parsi MA, Lourdusamy V, et al. Volatile organic compounds in bile for early diagnosis of cholangiocarcinoma in patients with primary sclerosing cholangitis: A pilot study. Gastrointest Endosc 2015 Apr;81(4):943-9.e1.

24. Skipworth JR, Keane MG, Pereira SP. Update on the management of cholangiocarcinoma. Dig Dis 2014;32(5):570-8.

25. Madhusudhan KS, Gamanagatti S, Gupta AK. Imaging and interventions in hilar cholangiocarcinoma: A review. World J Radiol 2015 Feb 28;7(2):28-44.

26. Levy MJ, Heimbach JK, Gores GJ. Endoscopic ultrasound staging of cholangiocarcinoma. Curr Opin Gastroenterol 2012 May;28(3):244-52.

27. Sapisochin G, Fidelman N, Roberts JP, Yao FY. Mixed hepatocellular cholangiocarcinoma and intrahepatic cholangiocarcinoma in patients undergoing transplantation for hepatocellular carcinoma. Liver Transpl 2011 Aug;17(8):934-42.

28. Masuoka HC, Rosen CB. Transplantation for cholangiocarcinoma. Clin Liver Dis 2011 Nov;15(4):699-715.

29. Sapisochín G, Fernández de Sevilla E, Echeverri J, Charco R. Liver transplantation for cholangiocarcinoma: Current status and new insights. World J Hepatol 2015 Oct 8;7(22):2396-403. 
30. Rosen CB, Heimbach JK, Gores GJ. Liver transplantation for cholangiocarcinoma. Transpl Int 2010 Jul;23(7):692-7.

31. Chung V. Systemic therapy for hepatocellular carcinoma and cholangiocarcinoma. Surg Oncol Clin N Am 2015 Jan;24(1):187-98.

32. Valle JW, Furuse J, Jitlal M, et al. Cisplatin and gemcitabine for advanced biliary tract cancer: A meta-analysis of two randomised trials. Ann Oncol 2014 Feb;25(2):391-8.

33. Benson AB 3rd, Bekaii-Saab T, Ben-Josef E, et al. Hepatobiliary cancers: Clinical practice guidelines in oncology. J Natl Compr Canc Netw 2006 Sep;4(8):728-50.

34. Zhu AX. Future directions in the treatment of cholangiocarcinoma. Best Pract Res Clin Gastroenterol 2015 Apr;29(2):355-61.

35. Rogers JE, Law L, Nguyen VD, et al. Second-line systemic treatment for advanced cholangiocarcinoma. J Gastrointest Oncol 2014 Dec;5(6):408-13.

36. Lee J, Park SH, Chang HM, et al. Gemcitabine and oxaliplatin with or without erlotinib in advanced biliary-tract cancer: A multicentre, open-label, randomised, phase 3 study. Lancet Oncol 2012 Feb;13(2):181-8.

37. El-Khoueiry AB, Rankin CJ, Ben-Josef E, et al. SWOG 0514: A phase II study of sorafenib in patients with unresectable or metastatic gallbladder carcinoma and cholangiocarcinoma. Invest New Drugs 2012 Aug;30(4):1646-51.

38. Ben-Josef E, Guthrie KA, El-Khoueiry AB, et al. SWOG So809: A phase II intergroup trial of adjuvant capecitabine and gemcitabine followed by radiotherapy and concurrent capecitabine in extrahepatic cholangiocarcinoma and gallbladder carcinoma. J Clin Oncol 2015 Aug 20;33(24):261722.

39. Malka D, Cervera P, Foulon S, et al. Gemcitabine and oxaliplatin with or without cetuximab in advanced biliary-tract cancer (BINGO): A randomised, openlabel, non-comparative phase 2 trial. Lancet Oncol 2014 Jul;15(8):819-28.

40. Denlinger CS, Meropol NJ, Li T, et al. A phase II trial of the proteasome inhibitor bortezomib in patients with advanced biliary tract cancers. Clin Colorectal Cancer 2014 Jun;13(2):81-6.

41. Park DH, Lee SS, Park SE, et al. Randomised phase II trial of photodynamic therapy plus oral fluoropyrimidine, S-1, versus photodynamic therapy alone for unresectable hilar cholangiocarcinoma. Eur J Cancer 2014 May;50(7):1259-68.

42. El-Khoueiry AB, Rankin C, Siegel AB, et al. So941: A phase 2 SWOG study of sorafenib and erlotinib in patients with advanced gallbladder carcinoma or cholangiocarcinoma. Br J Cancer 2014 Feb 18;110(4):882-7.

43. Sohal DP, Mykulowycz K, Uehara T, et al. A phase II trial of gemcitabine, irinotecan and panitumumab in advanced cholangiocarcinoma. Ann Oncol 2013 Dec;24(12):3061-5.

44. Rubovszky G, Láng I, Ganofszky E, et al. Cetuximab, gemcitabine and capecitabine in patients with inoperable biliary tract cancer: A phase 2 study. Eur J Cancer 2013 Dec;49(18):3806-12.
45. Borbath I, Ceratti A, Verslype C, et al. Combination of gemcitabine and cetuximab in patients with advanced cholangiocarcinoma: A phase II study of the Belgian Group of Digestive Oncology. Ann Oncol 2013 Nov;24(11):2824-9.

46. Lee JK, Capanu M, O’Reilly EM, et al. A phase II study of gemcitabine and cisplatin plus sorafenib in patients with advanced biliary adenocarcinomas. Br J Cancer 2013 Aug 20;109(4):915-9.

47. Yamanaka K, Hatano E, Kanai M, et al. A singlecenter analysis of the survival benefits of adjuvant gemcitabine chemotherapy for biliary tract cancer. Int J Clin Oncol 2014;19(3):485-9.

48. Sasaki $\mathrm{T}$, Isayama $\mathrm{H}$, Nakai $\mathrm{Y}$, et al. A randomized phase II study of gemcitabine and S-1 combination therapy versus gemcitabine monotherapy for advanced biliary tract cancer. Cancer Chemother Pharmacol 2013 Apr;71(4):973-9.

49. Jensen LH, Lindebjerg J, Ploen J, Hansen TF, Jakobsen A. Phase II marker-driven trial of panitumumab and chemotherapy in KRAS wild-type biliary tract cancer. Ann Oncol 2012 Sep;23(9):2341-6.

50. Roth A, Schleyer E, Schoppmeyer K, et al. Imatinib mesylate for palliative second-line treatment of advanced biliary tract cancer: A bicentric phase II study. Onkologie 2011;34(8-9):469-70.

51. Kemeny NE, Schwartz L, Gönen M, et al. Treating primary liver cancer with hepatic arterial infusion of floxuridine and dexamethasone: Does the addition of systemic bevacizumab improve results? Oncology 2011;80(3-4):153-9.

52. Iqbal S, Rankin C, Lenz HJ, et al. A phase II trial of gemcitabine and capecitabine in patients with unresectable or metastatic gallbladder cancer or cholangiocarcinoma: Southwest oncology group study So202. Cancer Chemother Pharmacol 2011 Dec;68(6):1595-602.

53. OhSY, Jeong CY, Hong SC, etal.PhaseIIstudy of second line gemcitabine single chemotherapy for biliary tract cancer patients with 5 -fluorouracil refractoriness. Invest New Drugs 2011 Oct;29(5):1066-72.

54. Bekaii-Saab T, Phelps MA, Li X, et al. Multiinstitutional phase II study of selumetinib in patients with metastatic biliary cancers. J Clin Oncol 2011 Jun 10;29(17):2357-63.

55. Iwahashi S, Utsunomiya T, Imura S, et al. Effects of valproic acid in combination with $\mathrm{S}-1$ on advanced pancreatobiliary tract cancers: Clinical study phases I/II. Anticancer Res 2014 Sep;34(9):5187-91.

56. Costello BA, Borad MJ, Qi Y, et al. Phase I trial of everolimus, gemcitabine and cisplatin in patients with solid tumors. Invest New Drugs 2014 Aug;32(4):7106.

57. Suder A, Ang JE, Kyle F, et al. A phase I study of daily afatinib, an irreversible ErbB family blocker, in combination with weekly paclitaxel in patients with advanced solid tumours. Eur J Cancer 2015 Nov;51(16):2275-84.

58. Isakoff SJ, Wang D, Campone M, et al. Bosutinib plus capecitabine for selected advanced solid tumours: Results of a phase 1 dose-escalation study. Br J Cancer 2014 Nov 25;111(11):2058-66.

59. Koido S, Homma S, Okamoto M, et al. Treatment with chemotherapy and dendritic cells pulsed with 
multiple Wilms' tumor 1 (WT1)-specific MHC class I/II-restricted epitopes for pancreatic cancer. Clin Cancer Res 2014 Aug 15;20(16):4228-39.

6o. Pant S, Saleh M, Bendell J, et al. A phase I dose escalation study of oral c-MET inhibitor tivantinib (ARQ 197) in combination with gemcitabine in patients with solid tumors. Ann Oncol 2014 Jul;25(7):1416-21.

61. Hickey R, Mulcahy MF, Lewandowski RJ, et al. Chemoradiation of hepatic malignancies: prospective, phase 1 study of full-dose capecitabine with escalating doses of yttrium-90 radioembolization. Int J Radiat Oncol Biol Phys 2014 Apr 1;88(5):1025-31.

62. Kobrinsky B, Joseph SO, Muggia F, et al. A phase I and pharmacokinetic study of oxaliplatin and bortezomib: Activity, but dose-limiting neurotoxicity. Cancer Chemother Pharmacol 2013 Nov;72(5):1073-8.

63. Pant S, Burris HA 3rd, Moore K, et al. A first-inhuman dose-escalation study of ME-143, a second generation $\mathrm{NADH}$ oxidase inhibitor, in patients with advanced solid tumors. Invest New Drugs 2014 Feb;32(1):87-93.

64. Plummer R, Madi A, Jeffels M, et al. A Phase I study of pazopanib in combination with gemcitabine in patients with advanced solid tumors. Cancer Chemother Pharmacol 2013 Jan;71(1):93-101.

65. Kurzrock R, Goel S, Wheler J, et al. Safety, pharmacokinetics, and activity of EZN-2208, a novel conjugate of polyethylene glycol and $\mathrm{SN}_{3} 8$, in patients with advanced malignancies. Cancer 2012 Dec 15;118(24):6144-51.

66. Konner J, Grisham RN, Park J, et al. Phase I clinical, pharmacokinetic, and pharmacodynamic study of KOS-862 (epothilone D) in patients with advanced solid tumors and lymphoma. Invest New Drugs 2012 Dec;30(6):2294-302.

67. Gore L, Rivera E, Basche M, et al. Phase I combination study of trabectedin and capecitabine in patients with advanced malignancies. Invest New Drugs 2012 Oct;30(5):1942-9.

68. Katayose Y, Rikiyama T, Motoi F, et al. Phase I trial of neoadjuvant chemoradiation with gemcitabine and surgical resection for cholangiocarcinoma patients (NACRAC study). Hepatogastroenterology 2011 NovDec;58(112):1866-72.

69. Howell M,ValleJW.Theroleofadjuvantchemotherapy and radiotherapy for cholangiocarcinoma. Best Pract Res Clin Gastroenterol 2015 Apr;29(2):333-43.

70. Tao R, Krishnan S, Bhosale PR, et al. Ablative radiotherapy doses lead to a substantial prolongation of survival in patients with inoperable intrahepatic cholangiocarcinoma: A retrospective dose response analysis. J Clin Oncol 2016 Jan 20;34(3):219-26.

71. Aljiffry M, Walsh MJ, Molinari M. Advances in diagnosis, treatment and palliation of cholangiocarcinoma: 1990-2009. World J Gastroenterol 2009 Sep 14;15(34):4240-62.

72. Lee TH, Moon JH, Park SH. Bilateral metallic stenting in malignant hilar obstruction. Clin Endosc 2014 Sep;47(5):440-6.

73. Singhal D, van Gulik TM, Gouma DJ. Palliative management of hilar cholangiocarcinoma. Surg Oncol 2005 Aug;14(2):59-74.

74. Lau SH, Lau WY. Current therapy of hilar cholangiocarcinoma. Hepatobiliary Pancreat Dis Int 2012 Feb;11(1):12-7.
75. Li Sol Y, Kim CW, Jeon UB, et al. Early infectious complications of percutaneous metallic stent insertion for malignant biliary obstruction. AJR Am J Roentgenol 2010 Jan;194(1):261-5.

76. Calcara C, Broglia L, Comi G, Balzarini M. Plastic biliary stent migration during multiple stents placement and successful endoscopic removal using intra-stent balloon inflation technique: A case report and literature review. Am J Case Rep 2016 Feb 5;17:65-9.

77. Ockenga J, Valentini L. Review article: Anorexia and cachexia in gastrointestinal cancer. Aliment Pharmacol Ther 2005 Oct 1;22(7):583-94.

78. Grenader T, Nash S, Plotkin Y, et al. Derived neutrophil lymphocyte ratio may predict benefit from cisplatin in the advanced biliary cancer: The ABC-02 and BT-22 studies. Ann Oncol 2015 Sep;26(9):19106.

79. Oshikiri T, Miyamoto M, Shichinohe T, et al. Prognostic value of intratumoral CD8+ T lymphocyte in extrahepatic bile duct carcinoma as essential immune response. J Surg Oncol 2003 Dec;84(4):2248.

8o. Takagi S, Miyagawa S, Ichikawa E, et al. Dendritic cells, T-cell infiltration, and Grp94 expression in cholangiocellular carcinoma. Hum Pathol 2004 Jul;35(7):881-6.

81. Goeppert B, Frauenschuh L, Zucknick M, et al. Prognostic impact of tumour-infiltrating immune cells on biliary tract cancer. Br J Cancer 2013 Nov 12;109(10):2665-74.

82. Marks EI, Yee NS. Immunotherapeutic approaches in biliary tract carcinoma: Current status and emerging strategies. World J Gastrointest Oncol 2015 Nov 15;7(11):338-46.

83. Jendrek ST, Gotthardt D, Nitzsche T, et al. Anti-GP2 IgA autoantibodies are associated with poor survival and cholangiocarcinoma in primary sclerosing cholangitis. Gut 2017 Jan;66(1):137-44.

84. Herbst RS, Baas P, Kim DW, et al. Pembrolizumab versus docetaxel for previously treated, PD-L1positive, advanced non-small-cell lung cancer (KEYNOTE-O10): A randomised controlled trial. Lancet 2016 Apr 9;387(10027):1540-50.

85. Weber JS, D’Angelo SP, Minor D, et al. Nivolumab versus chemotherapy in patients with advanced melanoma who progressed after anti-CTLA-4 treatment (CheckMate 037): A randomised, controlled, open-label, phase 3 trial. Lancet Oncol 2015 Apr;16(4):375-84.

86. Borghaei H, Paz-Ares L, Horn L, et al. Nivolumab versus docetaxel in advanced nonsquamous nonsmall-cell lung cancer. N Engl J Med 2015 Oct 22;373(17):1627-39.

87. Motzer RJ, Escudier B, McDermott DF, et al. Nivolumab versus everolimus in advanced renal-cell carcinoma. N Engl J Med 2015 Nov 5;373(19):180313 .

88. Ha H, Nam AR, Bang JH, et al. Soluble programmed death-ligand 1 (SPDL1) and neutrophil-to-lymphocyte ratio (NLR) predicts survival in advanced biliary tract cancer patients treated with palliative chemotherapy. Oncotarget 2016 Nov 22;7(47):76604-12.

89. Czink E, Kloor M, Goeppert B, et al. Successful immune checkpoint blockade in a patient with 
advanced stage microsatellite-unstable biliary tract cancer. Cold Spring Harb Mol Case Stud 2017 Sep 1;3(5). pii: aoo1974.

90. Rea DJ, Heimbach JK, Rosen CB, et al. Liver transplantation with neoadjuvant chemoradiation is more effective than resection for hilar cholangiocarcinoma. Ann Surg 2005 Sep;242(3):4518; discussion 458-61.

91. Provenzano PP, Hingorani SR. Hyaluronan, fluid pressure, and stromal resistance in pancreas cancer. Br J Cancer 2013 Jan 15;108(1):1-8.

92. Kultti A, Rilla K, Tiihonen R, Spicer AP, Tammi RH, Tammi MI. Hyaluronan synthesis induces microvillus-like cell surface protrusions. J Biol Chem 2006 Jun 9;281(23):15821-8.

93. Stylianopoulos T, Jain RK. Combining two strategies to improve perfusion and drug delivery in solid tumors. Proc Natl Acad Sci U S A. 2013 Nov 12;110(46):18632-7.

94. Thompson CB, Shepard HM, O'Connor PM, et al. Enzymatic depletion of tumor hyaluronan induces antitumor responses in preclinical animal models. Mol Cancer Ther 2010 Nov;9(11):3052-64.

95. Lv H, Yu G, Sun L, Zhang Z, Zhao X, Chai W. Elevate level of glycosaminoglycans and altered sulfation pattern of chondroitin sulfate are associated with differentiation status and histological type of human primary hepatic carcinoma. Oncology 2007;72(56):347-56.

96. Sato N, Cheng XB, Kohi S, Koga A, Hirata K. Targeting hyaluronan for the treatment of pancreatic ductal adenocarcinoma. Acta Pharm Sin B 2016 Mar;6(2):101-5.

97. Hingorani SR, Harris WP, Beck JT, et al. Phase Ib study of PEGylated recombinant human hyaluronidase and gemcitabine in patients with advanced pancreatic cancer. Clin Cancer Res 2016 Jun 15;22(12):2848-54.
98. Brandi G, Farioli A, Astolfi A, Biasco G, Tavolari S. Genetic heterogeneity in cholangiocarcinoma: A major challenge for targeted therapies. Oncotarget 2015 Jun 20;6(17):14744-53.

99. Fraveto A, Cardinale V, Bragazzi MC, et al. Sensitivity of human intrahepatic cholangiocarcinoma subtypes to chemotherapeutics and molecular targeted agents: A study on primary cell cultures. PLoS One 2015 Nov 16;10(11):e0142124.

100. Chong DQ,ZhuAX. Thelandscape of targeted therapies for cholangiocarcinoma: Current status and emerging targets. Oncotarget $2016 \mathrm{Jul}$ 19;7(29):46750-67.

101. Voss JS, Holtegaard LM, Kerr SE, et al. Molecular profiling of cholangiocarcinoma shows potential for targeted therapy treatment decisions. Hum Pathol $2013 \mathrm{Jul} ; 44(7): 1216-22$.

102. Raggi C, Invernizzi $\mathrm{P}$, Andersen JB. Impact of microenvironment and stem-like plasticity in cholangiocarcinoma: Molecular networks and biological concepts. J Hepatol 2015 Jan;62(1):198207.

103. Marks EI, Yee NS. Molecular genetics and targeted therapeutics in biliary tract carcinoma. World $\mathrm{J}$ Gastroenterol 2016 Jan 28;22(4):1335-47.

104. Ngernyuang N, Seubwai W, Daduang S, Boonsiri $\mathrm{P}$, Limpaiboon T, Daduang J. Targeted delivery of 5 -fluorouracil to cholangiocarcinoma cells using folic acid as a targeting agent. Mater Sci Eng C Mater Biol Appl 2016 Mar;60:411-5.

105. Jiao Y, Pawlik TM, Anders RA, et al. Exome sequencing identifies frequent inactivating mutations in BAP1, ARID1A and PBRM1 in intrahepatic cholangiocarcinomas. Nat Genet 2013 Dec;45(12):1470-3.

106. Churi CR, Shroff R, Wang Y, et al. Mutation profiling in cholangiocarcinoma: Prognostic and therapeutic implications. PLoS One 2014 Dec 23;9(12):e115383.
Access full text article on other devices

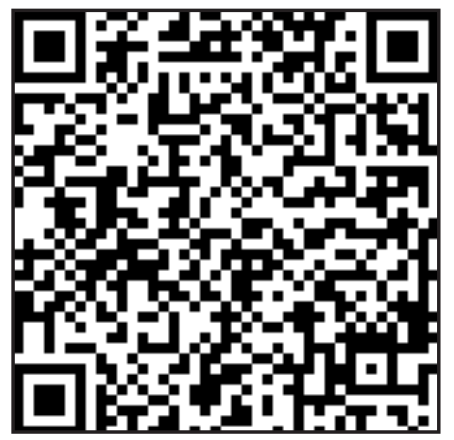

Access PDF of article on other devices

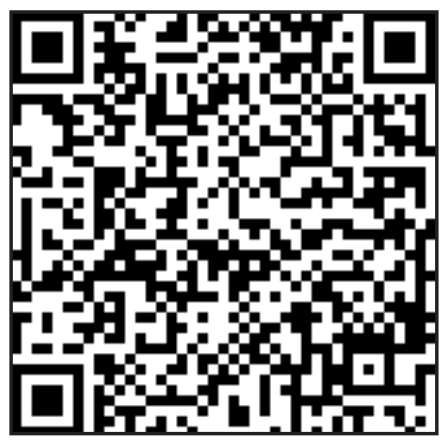

